\title{
Distribution of oral ulceration cases in Oral Medicine Integrated Installation of Universitas Padjadjaran Dental Hospital
}

\author{
Dewi Zakiawati ${ }^{1 *}$, Nanan Nur'aeny ${ }^{1}$, Riani Setiadhi ${ }^{1}$ \\ 1*Department of Oral Medicine, Faculty of Dentistry Universitas Padjadjaran, Indonesia
}

\begin{abstract}
Introduction: Oral ulceration defines as discontinuity of the oral mucosa caused by the damage of both epithelium and lamina propria. Among other types of lesions, ulceration is the most commonly found lesion in the oral mucosa, especially in the outpatient unit. Oral Medicine Integrated Installation (OMII) Department in Universitas Padjadjaran Dental Hospital serves as the centre of oral health and education services, particularly in handling outpatient oral medicine cases. This research was the first study done in the Department which aimed to observe the distribution of oral ulceration in OMII Department university Dental Hospital. The data is essential in studying the epidemiology of the diseases. Methods: The research was a descriptive study using the patient's medical data between 2010 and 2012. The data were recorded with Microsoft ${ }^{\circledast}$ Excel, then analysed and presented in the table and diagram using GraphPad Prism ${ }^{\circledast}$ Results: During the study, the distribution of oral ulceration cases found in OMII Department was 664 which comprises of traumatic ulcers, recurrent aphthous stomatitis, angular cheilitis, herpes simplex, herpes labialis, and herpes zoster. Additionally, more than $50 \%$ of the total case was recurrent aphthous stomatitis, with a precise number of 364 . Conclusion: It can be concluded that the OMII Department in university Dental Hospital had been managing various oral ulceration cases, with the most abundant cases being recurrent aphthous stomatitis.
\end{abstract}

Keywords: Epidemiology, oral ulceration, recurrent aphthous stomatitis.

p-ISSN: 1979-0201; e-ISSN: 2549-6212; Available from: http://jurnal.unpad.ac.id/pjd/article/view/23664

DOI: 10.24198/pjd.vol32no3.23664

Submission: Sep 17, 2019; Accepted: Nov 28, 2020; Published online: Nov 30, 2020

\section{INTRODUCTION}

Oral ulceration generally defined as discontinuity of the oral mucosa caused by damage of both epithelium and lamina propria of the oral mucosa. ${ }^{1,2}$ It has been estimated that around $40 \%$ of the population suffers with mouth ulcer. ${ }^{3}$ Patients usually present with a painful ulcer that may affect any oral mucosa, and this causing various conditions, such as taste disturbances, difficulties while talking, eating and swallowing, which might leads to eating reluctance, or even disrupt the ability of performing oral hygiene procedures. ${ }^{1,4}$ Furthermore, oral ulceration is one of the main reason for the patients to seek treatment and has been associated with impaired quality of life. ${ }^{2,4}$

"Corresponding author: Dewi Zakiawati, Department of Oral Medicine, Faculty of Dentistry Universitas Padjadjaran, Indonesia. Jalan Sekeloa Selatan I, Bandung, Indonesia, 40132. Phone: +6281214514225; e-mail: dewi.zakiawati@fkg. unpad.ac.id 
Universitas Padjadjaran Dental Hospital was established in 2003. The next following years, in 2006, Oral Medicine Unit - nowadays known as Oral Medicine Integrated Installation (OMII) Department - served as a unit specialising in oral disease complaints. Previously, together with the Dental Radiology Unit, the Department mainly provides oral maxillofacial and dental examination before the patient is referred to another relevant unit. However, since the Department was relocated to a new building, equipped with more facilities, as well as employing qualified dentists and oral medicine specialists, the services have been improved. To date, it does not only provide a general examination but also performs comprehensive management of various oral diseases. The dental hospital also builds special care units (named Paviliun Padjadjaran) to treat more advanced oral and dental cases, such as oral lichen planus, oral pemphigus vulgaris, etc., undergo by the specialists. ${ }^{5}$

The vision of Universitas Padjadjaran Dental Hospital is to become a teaching hospital. ${ }^{5}$ Therefore, patients who come to the OMII Department are treated by the dentist in charge and assisted by the dental co-assistant. As an implementation of the curriculum, these assistants should carry out special requirements in the Department, such as helping the dentist in monitoring patients with oral ulcerative and non-ulcerative cases. Despite all the cases being recorded since the service was running, no study has been done to analyse the distribution of the cases. There are numerous epidemiological studies in dental caries and periodontal diseases, but the epidemiology of oral mucosal condition, whether in children or adults is still limited, ${ }^{6,7}$ although oral ulcerations are encountered frequently in daily dental practice. This may lead to the neglect of the awareness towards the disease itself.

The World Health Organization (WHO) has recommended the oral health epidemiological surveillance, ${ }^{8}$ which support a thorough understanding of the epidemiology of the disease, and will reveal the risk factors of the illness. ${ }^{9}$ Nonetheless, the number of researches in the oral health epidemiology area is still considerably low. Therefore, our study was aimed to observe the distribution of oral ulceration cases in OMII Department university Dental Hospital to provide epidemiological information and serves as a baseline data for future research in the area of oral disease. Hence, help to improve oral health, particularly in Indonesia.

\section{METHODS}

The research was descriptive. Patient's medical records from 2010-2012 were collected, and to avoid duplication we only included the patient's diagnosis on the first visit to the OMII Department, while the medical data without oral ulceration diagnosis were excluded. The medical records were reviewed and assessed in the Department by a general dentist and two oral medicine specialists. After collecting all the data, we recorded and classified the diagnosis in Microsoft $^{\circledR}$ Excel. Subsequently, the database was analysed and presented in the form of table and diagram using GraphPad Prism ${ }^{\circledR}$.

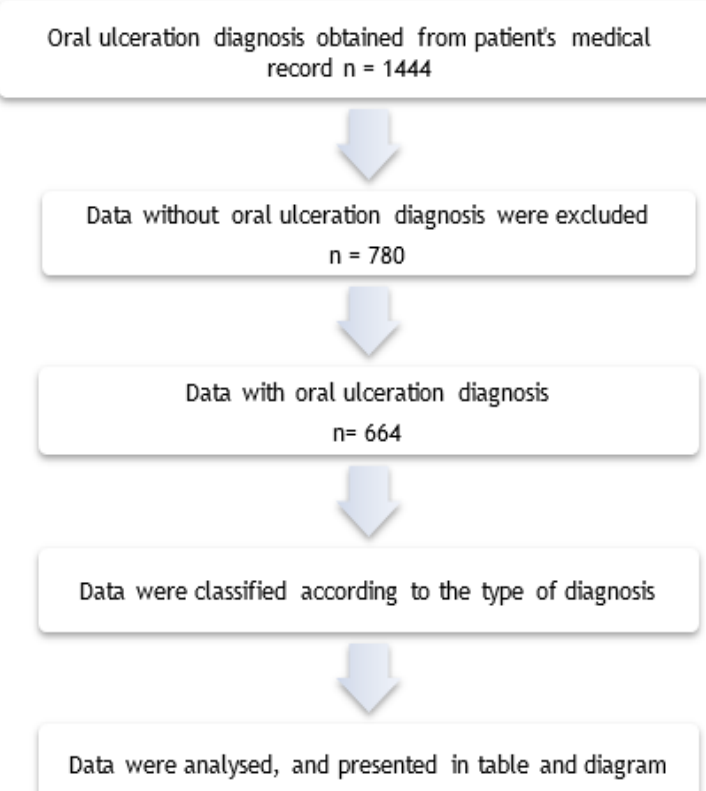

Figure 1. Research procedures. As many of 1,444 oral disease diagnoses were found from the patient's first visit between 2010 and 2012. The ulcerative cases were 644, and thus the remaining $\mathbf{8 0 0}$ diagnoses were excluded from the study. The data were recorded each month, classified based on the ulcerative diagnosis, and finally, presented in tables and diagrams.

These procedures were presented in Figure 1. We followed all the ethical principles for secondary data research, which are respect for persons, beneficence and non-maleficence, and justice. ${ }^{10}$ Moreover, we also made sure that the 
results do not allow re-identifying participants nor causing any damage or distress to the subject. Last, considering the research was using secondary data, consent of the subjects is reasonably presumed. ${ }^{11}$

\section{RESULTS}

The number of new patients visiting the OMII Department during 2010-2012 were as many as 1268 patients. The patients who came to control their oral lesions were 1,220 patients (Table 1).

Table 1. Number of patients in OMII Department during 2010-2012

\begin{tabular}{ccc}
\hline \multirow{2}{*}{ Year } & \multicolumn{2}{c}{ Number of patients } \\
& First visit & Control \\
\hline 2010 & 321 & 289 \\
2011 & 448 & 396 \\
2012 & 499 & 535 \\
Total & 1268 & 1220 \\
\hline
\end{tabular}

In total, 2,488 patients had visited the Department. The data also showed a significant increase in patient's visit each year; from 610 patients in the first year, raised to 844 patients, and in 2012, the number of patients reached 1,034 persons (Figure 2).

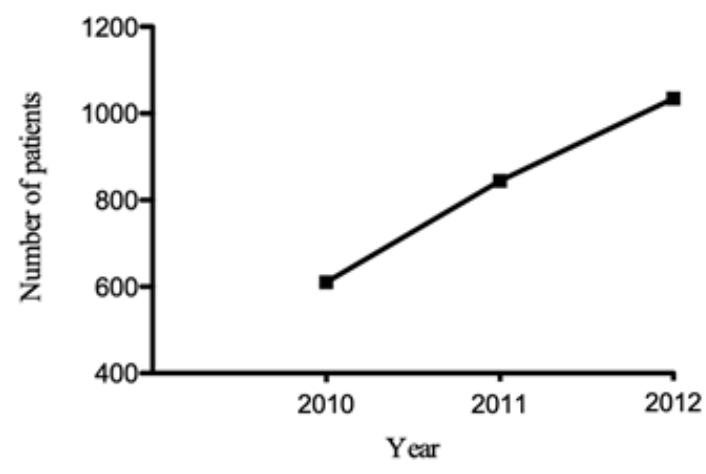

Figure 2. The increasing number of patients in the OMI Department during 2010-2012. The data showed an increase in the number of patients each year.

There was a 1444 oral diseases diagnosis recorded from the patient's medical data. The non-ulcerative diagnosis was excluded, leaving 664 data as samples (Table 2). The oral ulceration diagnosis was varied, including recurrent aphthous stomatitis (RAS), traumatic ulcer (TU), angular cheilitis (AC), herpes simplex (HS), herpes labialis
$(\mathrm{HL})$, and herpes zoster $(\mathrm{HZ})$. The number of diagnosis from the most found diagnosis to the least one is as follows: RAS was found in 364 cases, followed by TU in 286 cases, AC 10 cases, HS 2 cases, and lastly, $\mathrm{HL}$ and $\mathrm{HZ}$ both 1 case (Table 3). The data were also presented in a pie chart, showing the percentage of each oral ulceration diagnosis (Figure 3).

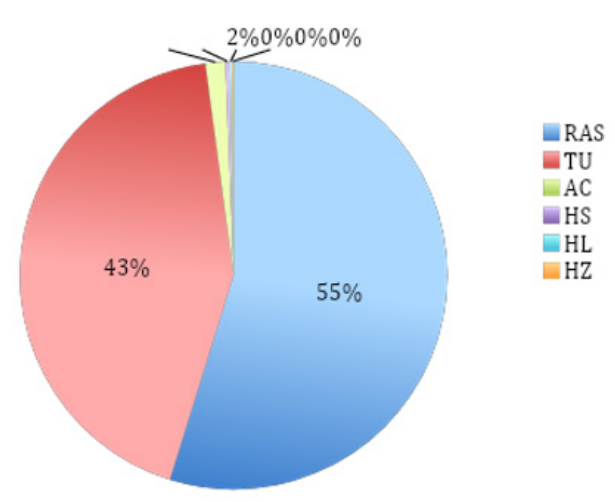

Figure 3. The percentage of oral ulceration found in the OMII Department. The diagnosis recorded for three years were including, recurrent aphthous stomatitis (RAS), traumatic ulcer (TU), angular cheilitis (AC), herpes simplex (HS), herpes labialis $(\mathrm{HL})$, and herpes zoster $(\mathrm{HZ})$. The percentage of each oral ulceration diagnosis was presented in the pie chart with details as follows: $55 \%$ for RAS (blue), $43 \%$ for TU (red), $2 \%$ for AC (green). While the three herpes types are rarely found $(\mathrm{HS}, \mathrm{HL}$, and $\mathrm{HZ}$ were consecutively displayed in purple, tosca, and orange).

Table 2. Cumulative number of oral disease diagnosis from 2010 to 2012

\begin{tabular}{cc}
\hline \multicolumn{3}{c}{ Oral disease diagnosis } \\
\hline Ulcerative diagnosis & Non-ulcerative diagnosis \\
664 & 780 \\
\hline
\end{tabular}

Table 3. Number of oral ulcerative diagnosis in three years

\begin{tabular}{|c|c|c|c|c|c|c|}
\hline \multirow{2}{*}{ Year } & \multicolumn{6}{|c|}{ Oral ulcerative diagnosis } \\
\hline & RAS $^{1}$ & $\mathrm{TU}^{2}$ & $\mathrm{AC}^{3}$ & $\mathrm{HS}^{4}$ & $\mathrm{HL}^{5}$ & $\mathrm{HZ}^{6}$ \\
\hline 2010 & 107 & 59 & 2 & - & - & - \\
\hline 2011 & 119 & 109 & 6 & 1 & - & 1 \\
\hline 2012 & 138 & 118 & 2 & 1 & 1 & - \\
\hline Total & 364 & 286 & 10 & 2 & 1 & 1 \\
\hline \multicolumn{7}{|l|}{ Notes: } \\
\hline \multicolumn{4}{|c|}{${ }^{1}$ Recurrent aphthous stomatitis } & \multicolumn{3}{|c|}{${ }^{4}$ Herpes simplex } \\
\hline \multicolumn{4}{|c|}{${ }^{2}$ Traumatic ulcer } & \multicolumn{3}{|c|}{${ }^{5}$ Herpes labialis } \\
\hline \multicolumn{4}{|c|}{${ }^{3}$ Angular cheilitis } & \multicolumn{3}{|c|}{${ }^{6}$ Herpes zoster } \\
\hline
\end{tabular}

\section{DISCUSSION}

Compliance or adherence is the behaviour of the patients in following therapeutic indications from 
the health care providers, ${ }^{12-14}$ including instructions to do the control visit. Good cooperation from the patient is important in supporting prognosis, and on the contrary, poor compliance resulting in disease progression. ${ }^{13}$ The number of new patients visited the OMII Department (1268) were only slightly higher than the follow-up visit (1220) (Table 1). It showed that most of the patients revisited the Department $(96,21 \%)$.

One of the factors that can contribute to these patient's adherence is the nonpharmacology treatment delivered by dental co-assistant, which is individual communication, information, and education (KIE)..$^{15}$ As mentioned in the Clinical Practice Guidelines for Dentist, these approaches are the first step in oral care procedures. ${ }^{16}$ This encompasses communicating the treatment procedures, where patients are also motivated to arrange 1-week post-therapy appointment, informing the patient about the disease, treatment options, risks, etc., as well as educating the patient on how to use the medication at home and how to maintain their oral health. Moreover, the young dentists should treat the patient comprehensively until the disease is resolved, and ensure the patient comes again for control.

The rising number of the patient's visits each year (Figure 2) was indicating the increase of oral disease awareness in the community. It is likely due to the massive publications from the community services program held annually, every October by the Dental Hospital supported by one of the biggest dentifrices companies in Indonesia to commemorate the national dental health month.

During the event, people can access oral care treatment for free, and the Dental Hospital admits around 1000 to 3000 patients. According to WHO, A comprehensive programme involving individual, professional, and community prevention programmes are effective in preventing oral diseases. ${ }^{8}$ As for many developing countries, intervention related to oral diseases is still rather sparse and unaffordable due to high cost, limited resources, and low cognizance.

Out of 1444 oral diseases diagnosis, the ulcerative lesion was slightly lower than the nonulcerative (Table 2). The reason for this difference is because the non-ulcerative lesion can be found in more than one case in a patient, for instance, a person can have a fissured tongue and coated tongue at once. The most recorded oral ulceration diagnosis was recurrent aphthous stomatitis, followed by traumatic ulcer, angular cheilitis, herpes simplex, and the least found diagnosis was herpes labialis and herpes zoster (Table 3 ).

Recurrent aphthous stomatitis (RAS) is the commonly found oral lesion in the community, with nearly $10-30 \%$ of the population are affected. ${ }^{17,18,19,20}$ Evidently, RAS was found in 55\% among all the oral ulceration cases (Figure 3). Following RAS, traumatic ulcer (TU) came next with $43 \%$ from the oral ulcerative diagnosis, and angular cheilitis (AC) came third with $2 \%$ (Figure 3). Previous studies have also confirmed that these types of lesions are also commonly found in the oral cavity. ${ }^{1,2,4,21}$

The aetiology of TU is varied. It can be due to physical trauma, including mechanical (sharp or broken teeth, wear oral appliances, bite), thermal, and electrical trauma. ${ }^{2}$ It can also cause by chemical, for example from aspirin as toothache remedies being placed in the mucosa of affected teeth. $^{22}$ It was reasonable that in this study TU appears as the second most popular diagnosis. The aetiology of $\mathrm{AC}$ is even more complex, comprising local and systemic conditions, such as decreased vertical dimension, and diabetes mellitus. For even more complicating the situation, the disease may involve secondary infection from Candida albicans, ${ }^{23}$ Streptococcus aureus, and even B-haemolytic streptococci. ${ }^{24}$

The least found oral ulcerative diagnosis was the herpes infections: herpes simplex, herpes labialis, and herpes zoster. People with normal or healthy status can also carry the herpes virus antibody and it will be increased during or postillness. ${ }^{25}$ Genital herpes (herpes simplex) mostly occurs in people who previously had type- 1 virus infection, such as herpes labialis. The infections are caused by the herpes simplex virus (HSV) type1 and type-2. ${ }^{26}$

Herpes infection can affect the airways, or extend to the rectum, and may enter the bloodstream causing serious ailment and can be extremely fatal. ${ }^{27}$ The reactivation of the varicellazoster virus is called herpes zoster. ${ }^{2}$ It is an acute self-limiting disease, characterised by a unilateral site of the lesion..$^{28}$ The reason why these diseases 
were rarely seen is that the Dental Hospital also has specialist units where most severe cases are treated by oral medicine specialist.During the study, the medical data in the Dental Hospital was still manually recorded. The system allowed high human errors, such as duplication, or worst, loss of data. For this reason, the computerised system is strongly suggested to improve the medical record registry and make it more accessible to epidemiological study.

The study provides preliminary data for future research, especially in the area of oral medicine. Epidemiology will help researchers and clinicians to understand the risk factor of the disease. ${ }^{29}$ Eventually, to improve individual and community oral health.

\section{CONCLUSION}

Although OMII Department in Universitas Padjadjaran Dental Hospital is relatively new in providing oral health care services, the Department had been managed a diverse range of oral ulcerations cases since 2010 until 2012, with the most commonly seen diagnosis was recurrent aphthous stomatitis and the least found diagnosis was herpes labialis and herpes zoster.

\section{ACKNOWLEDGEMENTS}

We would like to thank Universitas Padjadjaran for funding this research through Hibah Unpad program.

\section{REFERENCES}

1. Sundharam S, Sundararaman P, Kannan SK. Oral ulcers - A review. J Dent Oral Disord. 2018; 4(4): 1098.

2. Mortazavi H, Safi Y, Baharvand M, Rahmani S. Diagnostic features of common oral ulcerative lesions: An updated decision tree. Int J Dent. 2016; 2016:1-14. DOI: 10.1155/2016/7278925

3. NHS [homepage on internet]. London: 2020. Mouth ulcers. [cited 2020 Nov]; [about 4 screens]. Available from: https://www. nhsinform.scot/illnesses-and-conditions/ mouth/mouth-ulcer

4. Kurklu-Gurleyen E, Ogut-Erisen M, Cakir O, Uysal O, Ak G. Quality of life in patients with recurrent aphthous stomatitis treated with a mucoadhesive patch containing citrus essential oil. Patient Prefer Adherence. 2016; 10: 967-73. DOI: $10.2147 /$ PPA.S106530

5. RSGM Unpad [homepage on internet]. Bandung: 2019. Rumah Sakit Gigi dan Mulut Unpad. [cited 2019 Sep]; [about 2 screens]. Available from: http://rsgm.unpad.ac.id/

6. El Toum S, Cassia A, Bouchi N, Kassab I. Prevalence and distribution of oral mucosal lesions by sex and age categories: A retrospective study of patients attending Lebanese School of Dentistry. Int J Dent. 2018; 2018: 4030134. DOI: 10.1155/2018/4030134

7. Patil S, Kaswan S, Rahman F, Doni B. Prevalence of tongue lesions in the Indian population. J Clin Exp Dent. 2013; 5(3): e128-32. DOI: 10.4317/jced.51102

8. WHO [homepage on internet]. Geneva: 2019. Oral health - What is the burden of oal disease? [cited 2019 Sep]; [about 5 screens]. Available from: https://www.who.int/oral health/ disease_burden/global/en/

9. Lamont RJ, Jenkinson HF. Oral Microbiology at a Glance. Oxford: Wiley-Blackwell; 2010. p. 85.

10. Research Directorate. National guidelines for ethical conduct of research involving human subjects [Internet]. Khartoum: National Ministry of Health Directorate General of Health Planning and Research; 2008. 6-14 p. Available from: https://sites.google. com/site/healthresearchlibrary/nationalguidelines

11. Paolatubaro. Research ethics in secondary data: what issues? [Internet]. Data Big and Small. 2016 [cited 2020 Nov 10]. Available from: https://databigandsmall.com/2015/10/18/ research-ethics-in-secondary-data-whatissues/

12. Kalogianni A. Factors affect in patient adherence to medication regimen. Heal Sci J. 2011;5(3):157-8.

13. Arias-llorente RP, García CB, Martín JJD. The importance of adherence and compliance with treatment in cystic fibrosis. In: Sriramulu D, editor. Cystic Fibrosis - Renewed Hopes Through Research [Internet]. Asturias: Intech Europe; 2012. p. 455-72. Available from: www. intechopen.com

14. Zamaa MS, Sainudin. Hubungan kepatuhan 
pengobatan dengan kadar gula darah sewaktu pada pasien diabetes melitus tipe II. J Chem Inf Model. 2019;1(1):11-8.

15. Sisparyadi, Bintari A, Susilawati, Asriani PS, Fanggidae A, Yuniarti, et al. Penggunaan media kie- perlindungan anak terpadu berbasis masyarakat (PATBM). Kementerian Pemberdayaan Perempuan dan Perlindungan Anak Republik Indonesia; 2017. 1-18 p.

16. Dewanto I, Sudono, Kartini D, Saraswati, Putri A, Dharmawan IR. Panduan praktik klinik bagi dokter gigi. Pengurus Besar Persatuan Dokter Gigi Indonesia. Jakarta: Kementerian kesehatan RI; 2014. p. 17, 21, 25, 31, 33, 93, 95, 98.

17. Rodríguez-Archilla A, Raissouni T. Clinical study of 200 patients with recurrent aphthous stomatitis. Gac Mex [Internet]. 2019 Jan 30;154(2):122-8. Available from: http:// gacetamedicademexico.com/frame_eng. php?id=122

18. Nur'aeny N, Sufiawati I, Suwarsa O, Gurnida DA. Serum IL-6 levels of atopic patients with recurrent aphthous stomatitis (RAS). 2019;31(1):20-4.

19. Bas Y, Yildiz Seckin H, Kalkan G, Takci Z, Onder $Y$, Citil R, et al. Investigation of behçet's disease and recurrent aphthous stomatitis frequency: the highest prevalence in turkey. Balkan Med J [Internet]. 2016 Aug 1;33(4):390-5. Available from: http://www.balkanmedicaljournal.org/ pdf.php?\&id=91

20. Bruch JM, Treister NS. Clinical Oral Medicine and Pathology [Internet]. Totowa, NJ: Humana Press; 2010. 176 p. Available from: http:// link.springer.com/10.1007/978-1-60327-520-0

21. Leão JC, Gomes VB, Porter S. Ulcerative lesions of the mouth: An update for the general medical practitioner. Clinics. 2007;62(6):76980.

22. Apriasari ML. The management of chronic traumatic ulcer in oral cavity. Dent J (Majalah Kedokt Gigi). 2012;45(2):68.

23. Jabra Rizk MA. Oral Candidiasis: An Opportunistic Infection of AIDS. J AIDS Clin Res. 2014;05(09):23-7.

24. Lugović-Mihić L. Differential diagnosis of cheilitis - how to classify cheilitis? Acta Clin Croat [Internet]. 2018;57(2):342-51. Available from: https://hrcak.srce.hr/index. php?show=clanak\&id clanak jezik $=304954$

25. Mustafa M, Illzam E, Muniandy R, Sharifah A, Nang $M$, Ramesh B. Herpes simplex virus infections, Pathophysiology and Management. IOSR J Dent Med Sci. 2016;15(07):85-91.

26. Igde FA, Taskin MH, Igde M, Erdem F, Yazici Z. Assessment of serological data of herpes simplex virus type 1 and 2 infections in Samsun, Turkey, 2012-2016. Southeast Asian J Trop Med Public Health. 2017;48(5):999-1005.

27. Gebreyohannes G. Human Herpes Simplex Virus Categories, Mode of Transmission, Treatment and Preventive Measures. Int J Pharm H Care Res. 2014;11(January):211-26.

28. Ayuningati LK, Indramaya DM. Studi Retrospektif: Karakteristik Pasien Herpes Zoster. Period Dermatology Venereol. 2015;27(3):211-7.

29. Broadbent A. Epidemiology, risk and causation health science. Cambridge: PHG Foundation; 2011. 1-24 p. 